\title{
THE NEED FOR
} ANTIMICROBIAL

PEPTIDES IN A WORLD

OF ANTIBIOTIC RESISTANCE

\author{
TERRI CAMESANO IS A PROFESSOR OF CHEMICAL ENGINEERING \\ AT WORCESTER POLYTECHNIC INSTITUTE IN THE US. MUCH OF \\ HER RESEARCH IS CONCERNED WITH PEPTIDES, SPECIFICALLY \\ THEIR ANTIMICROBIAL AND WOUND HEALING PROPERTIES. HER \\ FINDINGS COULD LEAD TO THE DEVELOPMENT OF STRATEGIES \\ TO TREAT BACTERIAL INFECTIONS
}

\section{IMAGINE THIS}

Alexander Fleming's discovery of penicillin was, in many respects, extremely fortunate. Before leaving for a two-week holiday, Fleming left a petri dish containing a staphylococcus (a type of bacteria) culture on a lab bench by accident (it was supposed to be placed inside an incubator).

Somehow, a Penicillium mould spore was accidentally introduced - most likely by floating up a stairwell from the laboratory below and upon his return from holiday, Fleming noticed that there was a bacteria-free zone in the petri dish, which inhibited the growth of staphylococci. This newly discovered active substance was effective even when diluted up to 800 times. He named it penicillin.

As Fleming later noted, "One sometimes finds what one is not looking for."

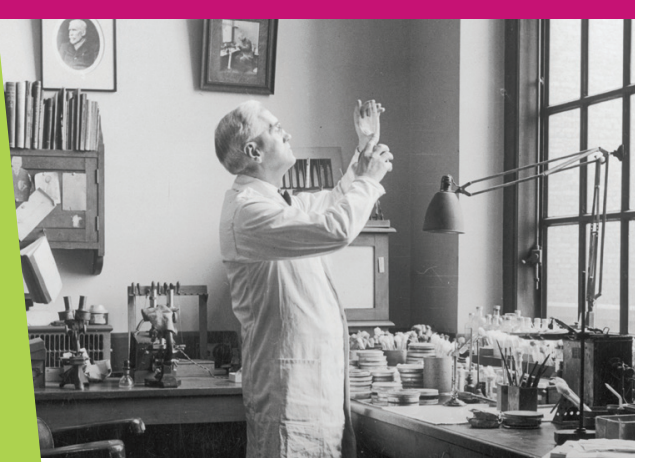

Antibiotics are a type of antimicrobial substance that is active against bacteria and is a vital means of fighting bacterial infections. It is difficult to overstate the importance of antibiotics in terms of treating a variety of conditions. Indeed, it is no exaggeration to say that antibiotics revolutionised medicine in the $20^{\text {th }}$ century, particularly with Alexander Fleming's discovery of penicillin in 1928. It would be impossible to calculate just how many lives have been saved by this important discovery.

However, the effectiveness of and easy access to antibiotics has led to their overuse and some bacteria have developed resistance. This is a major problem, with the World Health Organization saying that antibiotic resistance is one of the biggest threats to global health, food security, and development today. As a result, the world needs to quickly change the way it prescribes and uses antibiotics to limit the spread of antibiotic resistance.

Researchers around the world are investigating new methods of treating infections and other illnesses, ones that will reduce our reliance on antibiotics in the future. Terri Camesano is a professor of chemical engineering at Worcester Polytechnic Institute in the US. Much of her research is focused on antimicrobial peptides, which have a lot of potential to help people when they are developed into therapeutic treatments.

WHAT ARE ANTIMICROBIAL PEPTIDES?

Antimicrobial peptides are a class of natural molecules that are used by all types of single cell and multicellular organisms. Some of the ones that Terri and her group have worked with come from humans, fish, sheep, and even pigs, and they are part of their immune systems. They have the ability to kill fungi, viruses, bacteria, yeasts, and cancer cells. "I'm interested in them because they have unique antimicrobial properties," she explains. "For one thing, it is very difficult for humans to develop a resistance to antimicrobial peptides."

\section{WHAT APPLICATIONS COULD THEY} HAVE IN THE BIOMEDICAL AREA?

Antimicrobial peptides have great potential to be used to develop new antimicrobial and anti-infection treatments and therapies. Terri believes they will be especially important in developing strategies to treat bacterial infections that are resistant to our current group of antibiotics. Her team is also looking at whether antimicrobial peptides can be made into a coating that will be placed on biomedical devices, such as catheters or orthopaedic implants. This will help prevent many hospitalassociated infections. 


\section{. ABOUT CHEMICAL ENGINEERING}

Chemical engineering is applied chemistry. This branch of engineering is focused on the development of chemicals and the manufacture of products using chemical processes. This might include the designing of equipment and processes, through to the mixing and processing of chemicals to create products with a wide range of benefits.

Given this broad definition, chemical engineers generally need a broad skill set. They might apply the principles of chemistry, biology, physics, and mathematics to solve problems associated with the production or use of chemicals, fuel, drugs, and even food.

\section{WHAT CAREER ROUTES ARE} AVAILABLE WITH A CHEMICAL ENGINEERING DEGREE?

"I loved chemical engineering as an undergraduate major because it is so versatile. Graduates can go into many different fields, ranging from energy and environment to biotech, pharmaceuticals, petrochemicals, materials, and more," says Terri. "I also think the skills that we teach chemical engineers translate into many nontechnical areas, as well. We learn to solve problems, work in teams, stick to a budget, and communicate."
There are many possibilities and opportunities with a chemical engineering degree. While there are traditional paths, it can be used to do other things as well. If you really want to be a professor or start a business, you can do that! There are chemical engineers who have gone on to leadership roles in all types of industrial, academic, and government settings.

\section{WHAT SUBJECTS AND}

EXTRACURRICULAR ACTIVITIES

SHOULD YOU TAKE AT SCHOOL IF YOU ARE INTERESTED IN STUDYING CHEMICAL ENGINEERING?

"I would encourage any student studying engineering to take on some extracurricular activities that are complementary to their studies," explains Terri. "If you love photography, you can be an officer in the yearbook club or school newspaper. Having a chance to be in a leadership role in a club is also really good experience and will help you in your future career in engineering."

Students and engineers also often spend a lot of time sitting down, so it is important that you indulge in some physical activity, such as dancing or playing a sport, to keep you fit and healthy. Terri encourages everyone to study mathematics if they can and likes to remind her students that you do not have to be the best at any particular subject, and you do not have to be a "natural" at maths or science in order to become an engineer - the most important qualities are passion and a willingness to work hard.

ISN'T ENGINEERING FOR BOYS? WHY SHOULD MORE GIRLS STUDY CHEMICAL ENGINEERING?

"I truly believe that engineering is for everyone who wants to solve problems and make a difference in the world," says Terri. "In the US, about $18-20 \%$ of engineers are women. That number is steadily growing as more women rise up in the workplace. When I was first starting out, there were a lot fewer women in my field. However, I didn't let that stop me and stayed focused on my goals, while always seeking out mentors (men and women) who could help me."

Peer mentors are also really helpful. Early in Terri's career, she would meet regularly with a group of other assistant professors to share the challenges and triumphs of starting their independent careers.

\section{OPPORTUNITIES IN \\ CHEMICAL ENGINEERING}

- A chemical engineer can earn between $\$ 51,710$ and $\$ 66,286$ with less than a year's experience. This can rise to more than $\$ 120,000$ after 20 years' experience.

- ThoughtCo. has dedicated a webpage to explaining some of the top reasons to study engineering, including the fact that engineers are happy and make a difference!

https://www.thoughtco.com/why-study-engineering-604017

- There are chemical engineering internships across the US in a wide variety of sectors, many of which are professional development programmes.

https://graduateland.com/s/chemical-engineering-internships/ united-states

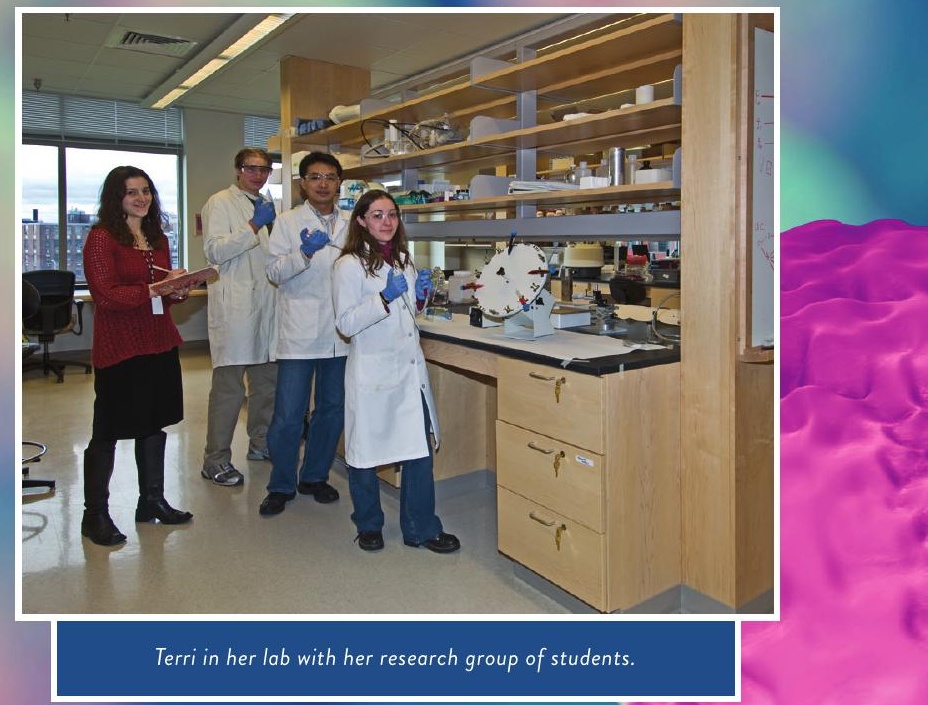


